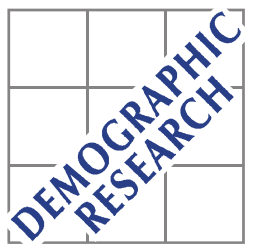

Demographic Research a free, expedited, online journal of peer-reviewed research and commentary in the population sciences published by the Max Planck Institute for Demographic Research Konrad-Zuse Str. 1, D-18057 Rostock · GERMANY www.demographic-research.org

DEMOGRAPHIC RESEARCH

VOLUME 27, ARTICLE 10, PAGES 261-298

PUBLISHED 21 AUGUST 2012

http://www.demographic-research.org/Volumes/Vol27/10/

DOI: 10.4054/DemRes.2012.27.10

Research Article

The second demographic transition in Israel:

One for all?

Evgenia Bystrov

(C) 2012 Evgenia Bystrov.

This open-access work is published under the terms of the Creative Commons Attribution NonCommercial License 2.0 Germany, which permits use, reproduction \& distribution in any medium for non-commercial purposes, provided the original author(s) and source are given credit.

See http:// creativecommons.org/licenses/by-nc/2.0/de/ 


\section{Table of Contents}

1 Introduction $\quad 262$

2 Theoretical background 263

$3 \quad$ Current research 265

$4 \quad$ Methodological considerations $\quad 267$

4.1 Data 268

$\begin{array}{ll}4.2 & 269\end{array}$

$5 \quad$ Results and discussion 269

5.1 Attitude and value change in Israel 269

5.2 Marital transition in Israel 272

$\begin{array}{lll}\text { 5.2.1 Marital behaviour and attitudes } & 272\end{array}$

5.2.2 Factors impeding marital transition 274

5.2.3 Alternatives to marriage 275

$\begin{array}{lll}5.3 & \text { Fertility transition in Israel } & 278\end{array}$

$\begin{array}{lll}\text { 5.3.1 Postponement of childbearing } & 278\end{array}$

5.3.2 Completed fertility in Israel 279

$\begin{array}{lll}\text { 5.3.3 Contraception behaviour } & 283\end{array}$

5.3.4 Implications of fertility transition 284

$\begin{array}{lll}6 & \text { Summary and conclusions } & 287\end{array}$

$\begin{array}{lll}7 & \text { Data appendix } & 288\end{array}$

$8 \quad$ Acknowledgements 289

$\begin{array}{ll}\text { References } & 290\end{array}$ 


\title{
The second demographic transition in Israel: One for all?
}

\author{
Evgenia Bystrov $^{1}$
}

\begin{abstract}
This paper explores family behaviours and attitudes in Israel over the last decades through the lens of the Second Demographic Transition (SDT). Israel is divided by religious affiliation, level of religiosity, ethnic origin, and timing of immigration. Although fertility transition to replacement level among certain societal groups has been previously shown, the question of how the transition unfolds in other domains remains open. The goal of this paper is to highlight the diversity of marital and fertility transitions and non-transitions among various groups of this heterogeneous society, and to compare Israel's transitions to those in Europe. The data sources which are used are cross-national large-scale surveys, national representative surveys, and Population Register data. The data were disaggregated by religion, religiousness, and ethnic origin. Emancipative value change, postponement of marriage, alternative living arrangements, and a growing variety of fertility regimes were analysed. A full range of pretransitional, transitional, and post-transitional elements was found among the groups. Such sign of the SDT as growing childlessness was not found, and the spread of other features such as unmarried cohabitation and non-marital childbearing were found to be limited. Population composition effects were isolated. It was found that the level of religiosity and the country of origin are important factors which differentiate family behaviours and attitudes. The connection between value orientation of the groups within Israel and their family behaviours is discussed. The socio-structural and institutional constraints that might impede further progression of the Second Demographic Transition in Israel are also discussed. Further research directions are suggested.
\end{abstract}

\footnotetext{
${ }^{1}$ Jacobs University Bremen and University of Bremen. E-mail: evgenia.bystrov@gmail.com.
} 


\section{Introduction}

Demographic transition is not a new theme in studies of fertility and family behaviour in Israel. Much has been said about Israel's transition to fertility replacement level and the role of immigration in this process (Friedlander and Feldmann 1993; Okun 1996; Friedlander et al. 1999; Friedlander 2002). In fact, Friedlander and Feldmann (1993) showed that the secular Israeli Jews of European origin have reached an advanced stage in fertility transition toward below replacement level, similarly to Europeans. However, the question of how the transition unfolds in other domains remains open.

What the present article adds to this debate is a quantification of the on-going changes through the theoretical lens of the Second Demographic Transition (SDT) (Lesthaeghe and van de Kaa 1986; van de Kaa 1987, 1996, 1997, 2001; Lesthaeghe 2010). In the paper a range of behaviours related to the SDT are analysed, not only fertility per se. This holistic approach allows synthesizing various demographic phenomena in a more integrative perspective, differentiating between the pretransitional, transitional, and post-transitional elements, and investigating the complex mechanism of the onset and diffusion of the transition process.

SDT is a broad term that describes a variety of changing family-related attitudes and behaviours. Lesthaeghe (2010) and van de Kaa (2001) distinguish between marital transition and fertility transition, which occur along with the societal value change. Marital transition refers to the postponement of marriage, the emergence of various types of living arrangements, and to alternative forms of cohabitation and procreation. The consequent fertility transition culminates in an overall postponement of childbearing, and a decrease in the eventual number of births.

The article is structured as follows: firstly, it tests to which degree a generational change in attitudes and value orientations has been pronounced among various population groups in Israel. Secondly, it shows which group has been altering family behaviour over time, and whether behavioural and attitudinal changes correspond. Essentially, the question of the SDT is a question of change in behaviours accompanied by change in attitudes. Such features of marital transition as postponement of marriage, rising cohabitation, tolerance of non-marital sexual relations, and of non-marital living arrangements are discussed. Thirdly, fertility transition and some of its consequences are analysed. Newly emerging fertility regimes, growing proportions of multiple births, and increasing age at motherhood are examples of phenomena related to fertility transition. Special attention is paid to the growing variety of mother profiles. Israel's patterns of the SDT are compared with Europe as a reference. Finally, the implications of the various groups' growth rates, increasing behavioural differences, and heterogeneity are discussed in light of the broader socio-cultural and political context. 


\section{Theoretical background}

SDT theory presumes that the rise of individual autonomy values in post-industrial economies is accompanied by the postponement of family formation and childbearing, greater instability of existing unions, and increasing variety of living arrangements and alternative lifestyles (Lesthaeghe and van de Kaa 1986; van de Kaa 1987). The widening opportunities in life, increasing freedom of choice, and the rising emphasis on emancipative values are nurtured to a large extent by an expansion of individual resources and progressing democratization, according to the revised theory of modernization and Human Empowerment framework (Welzel et al. 2003; Inglehart and Welzel 2005; Welzel and Inglehart 2010). However, path-dependent, contextual, and nation-specific factors alter the course of the demographic changes (Lesthaeghe 1998; Inglehart and Welzel 2010). Moreover, regional-historical context, social stratification, and diffusion mechanisms lead to a variation in family formation within a given society (Surkyn and Lesthaeghe 2004). Although Inglehart and Welzel (2010) show that variation in basic value orientations is generally smaller within than between societies, there might be exceptions. A case in point is Israel.

The current paper argues that under certain circumstances the societal level perspective falls short in explanations when faced with cleavages which divide societies internally. World views and mass beliefs held by various groups in Israeli society, as well as their demographic behaviour, resemble more an assembly of different world regions than segments of the same society. That is why studying Israel is potentially revealing. This society confronts us with a unique paradox that is of critical relevance in light of general theories. In socio-economic terms Israel is modern because it harbours a post-industrial knowledge economy that generates a high per capita income. In sociocultural terms, however, Israel might be considered a profoundly traditional society which preserves conservative family values (Lavee and Katz 2003), and consequently offers little ground to assume any transition whatsoever. High total fertility rates are not the least reason for this: the fertility levels are unusually high even among those Jewish sectors of the population that have made the transition to modernity (Anson and Meir 1996). This traditionalism/modernism paradox is the key to further understanding the profile of this particular society, and the nature and mechanism of the transition process in general.

Social stratification in all societies restricts human choice by limiting individual horizons (Welzel and Inglehart 2010). Although Israeli society as a whole might be viewed as rather traditional, the social groups vary greatly in their worldviews and value orientations. Social stratification in Israel is usually conceptualized in terms of belonging to the national majority of Jews (and others who are not classified by religion, the vast majority of whom are 1990s' immigrants from the former USSR) or 
the minority of Arabs (Moslems, who comprise about 18\% of total population, and Christians, about $2 \%$ of total population); among the Jews further division by ethnic origin takes place. Two major groups are those of Asian or North African origin and of European or American origin, and the largest ethnic group in 2009 is of Israel-born Jews (Figure1).

Figure 1: Characteristics of Israeli population by religious affiliation and ethnic origin

\section{Population by religious affiliation in 1949-2009}

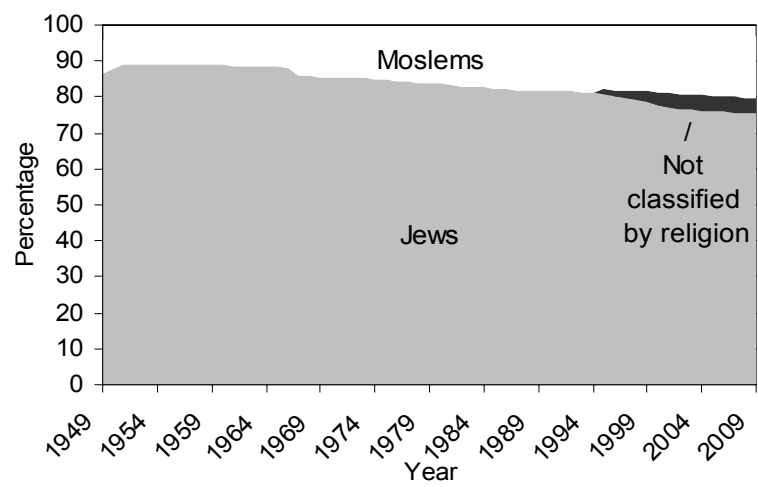

\section{Population by ethnic origin in 1948-2009}

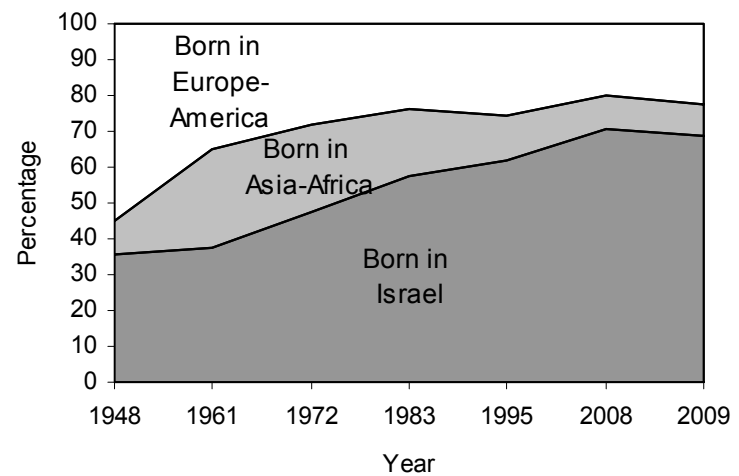


Besides ethnicity, Israel is stratified by the level of religious observance. Religiousness is considered an important determinant of family size (Friedlander and Goldscheider 1978), political behaviour (Shamir and Arian 1999), and way of life (Smooha 2005). Affiliation with a certain ethnic and religious social group implies belonging to a community with very distinct cultural norms, interests, and goals in life (Katz-Gerro et al. 2009). The vast majority of Jews in Israel are subject to the influences of one or more of these sub-cultures (Liebman 1997). In Israel's deeply divided society one of the most recognized social cleavages is between the secular majority and the Ultra Orthodox, who aim to impose their beliefs and norms on all aspects of public and private life (Smooha 2004).

The cleavage between religious and secular groups forms a continuum which is clearly based on their different worldviews, values, and norms. It is common in Israeli surveys to ask the participants - in addition to the standard self-definition of religious identity - to rate the level of their religious observance (Arian et al. 2008). In Israel 'objective' measures of religiousness, such as frequency of church attendance, would produce a distorted picture, since for Jews the synagogue functions not only as a place for praying and worshiping, but also as a gathering place for broader community purposes (educational, social, and political). That is, synagogue attendance is not necessarily a proxy for religiousness. Thus, self-definition of religious identity and rating the level of religious observance are considered a valid measure of the respondents' religiosity.

In $20098 \%$ of adult Jewish Israelis defined themselves as "Ultra Orthodox", 12\% as "religious", $13 \%$ as "traditional religious", $25 \%$ as "traditional non-religious", and $42 \%$ as "non-religious /secular". Among Moslem Israelis 10\% define themselves as "very religious", $51 \%$ as"religious", $29 \%$ as "not so religious", and $11 \%$ as "nonreligious" (Israel Central Bureau of Statistics 2010a). Since one of the basic prerequisites needed for the onset of the First and Second demographic transitions is the secularization of society (Lesthaeghe 2010), some sizeable and fiercely religious groups in Israel do not fit the typical transition profile.

\section{Current research}

SDT theory predicts the following chain of events as a consequence of ideational change toward more individualistic value orientation (van de Kaa 1987): postponement of marriage, a rise in alternative types of living arrangements, postponement of first births, a rise in late and out-of-wedlock childbearing, and a decrease in overall fertility. Thus the major components of SDT are a high proportion of women aged 25-29 never married, a rising percentage of currently cohabiting, late fertility schedule, and below 
replacement fertility. Additional components are high divorce rate, low frequency of abortions, and a high proportion of women using modern contraception. However, the sequence is not universal, some stages are country-specific, and, above all, there is within-country heterogeneity (Sobotka et al. 2003; Lesthaeghe and Neidert 2006; Sobotka 2008).

Some country-specific features hamper the onset and slow the diffusion of demographic transition in Israel. These are the state-religion relations and traditionalism of the society. Religion plays a key role in the public sphere (Liebman 1993, 1997; Fogiel-Bijaoui 2002; McQuillan 2004; Smooha 2005); the family laws are religious (Gottschalk 1951; Strum 1989), and gender roles are traditional (Semyonov and LewinEpstein 1991; Stier and Lewin-Epstein 2000; Safir et al. 2003; Toren 2003; Yaish and Kraus 2003; Stier and Yaish 2008). Nonetheless, Jewish Israelis are gradually adopting alternative lifestyles, self-expression values are rising (Yuchtman-Ya'ar 2002), and 'postmodern families' and such forms of union as cohabitation are slowly spreading (Katz 2001; Fogiel-Bijaoui 2002; Baloush-Kleiman and Sharlin 2004). The leaders of the change are secular Jews of European origin, educated, and residing in big cities (Fogiel-Bijaoui 2002). These recent findings of changing family behaviour lead to the first hypothesis in this paper:

1) Demographic trends associated with the SDT are primarily found among Jewish non-religious groups and groups of European origin. The religious continuum from secular pole to Ultra Orthodox reflects also in family behaviour and attitudes.

As mentioned earlier, the vast majority of Moslems are religious. The modernization of the Moslems' family patterns did not progress through the 1980s and the 1990s; therefore their fertility remained at relatively high levels (Friedlander 2002). Such behaviours as dating may be prohibited and the parents' consent is needed for a bride to get married (Lavee and Katz 2003). The domination of the religious law is interpreted as a facet of the Moslem community's cultural autonomy, and thus is tolerated (Fogiel-Bijaoui 2002). Hence, the second hypothesis can be derived:

2) The Moslem population is at a pre-transitional level.

Since existential security concerns and nationalistic outlook are still part of the geopolitical realm of many Israelis (Arian 1995, 2003, 2005; Smooha 2005), some features of the SDT might not be present. Previous findings regarding the national and socio-cultural profile of Israeli society show a preference for large families and that children are highly valued (Friedlander and Goldscheider 1978; Fogiel-Bijaoui 2002; Landau 2003; Lavee and Katz 2003; Nauck and Klaus 2007; Suckow 2008; DellaPergola 2009; Schellekens 2009). The family as a social construct is subject to social approval (Bourdieu 1996), leading to the encouragement of certain types of individual behaviour. Social feedback, normative influences, mechanisms of peer group pressure, and compelling role models initiate the so-called social interaction effects 
(Montgomery and Casterline 1996; Kohler et al. 2002). Prospective mothers enter a social realm which offers broad kin and public support for childrearing (Berkovitch 1997; Morgan and Berkowitz King 2001) and calls for compliance with group norms on childbearing, evidenced by pro-natal public policy (Friedlander 1973; Landau 2003; Manski and Mayshar 2003).

Moreover, the social milieu of the country (Nahmias 2004) establishes the overall moral norms and generates pressures that foster obedience. Israel is a relatively small country where social networking functions as a major dimension of social relations. Individuals are strongly connected to one another by familial, residential, linguistic, and friendship ties. These connections are highly emotional in nature, for Israelis' social relations are often described as warm, personal, and informal (Smooha 2005). Thus the existing traditional norms might influence the course of development in overall family behaviour. Further hypotheses read as follows:

3) Postponement of marriage and childbearing is followed by recuperation, so that most groups achieve above-replacement fertility.

4) Such characteristics of the SDT as widespread cohabitation, out-of-wedlock childbearing, and voluntarily childlessness are marginal in the repertoire of all Israeli groups' behaviours.

\section{Methodological considerations}

Does the comparison between demographic transitions in Western democracies and the demographic processes in Israel make sense? Under which conditions are these demographic developments comparable? Although Israel differs from the West in many basic characteristics (Smooha 2010), a working assumption of this research, following Smooha (2005), is that European countries are the natural units of comparison to Israel, for several reasons. Firstly, the majority of Israel's Jewry originates in Eastern and Central Europe, and many are West-oriented. Secondly, having a comparable standard of living, Israel is tied to the West by numerous political, military, economic, and cultural relations. Thirdly, the set of values known as 'the Protestant ethic' brings Israeli Jews closer to the West (Smooha 2005: 437).

Yet Israel's exceptional social heterogeneity should not be disregarded (Friedlander and Feldmann 1993). Over a quarter of Israel's total population is not Western and does not wish to be Western: Ultra Orthodox Jews "try hard to keep the old ways as much as possible, to reject Western values and to believe that redemption will come by strict observance of traditional Judaism" (Smooha 2005: 424), while Israeli Arabs identify themselves with the Arab world. These two groups are outstanding in their reproductive behaviour. In 2001 the total fertility rate (TFR) of 
Moslems was 4.7 children per woman, including the Bedouins in the south whose TFR was 9.2, and the TFR of Ultra Orthodox Jews was 7.7 (Gurovich and Cohen-Kastro 2004). Can there be any transition in sight for these groups?

Furthermore, these extraordinary fertility rates, vary rare in the $21^{\text {st }}$ century, create interesting statistical effects of population composition. That is, due to differential natural increase the population structure changes: the share in population of groups with the highest natural increase becomes more substantial over time. These compositional effects are a direct consequence of heterogeneity in reproduction, and therefore must be taken into account.

Finally, the discussion of Israel's family-related behaviour requires recognition of Israel as a conglomerate of groups with various national, ethnic, and religious backgrounds, and of the fact that significant fractions of the population are immigrants. The theme of how the mosaic of Israeli population has emerged is extensively described in the literature (see, for example, Friedlander 1975; Friedlander and Goldscheider 1978; Ben-Moshe 1989; Okun 1996; Friedlander et al. 2002; Philippov and Bystrov 2011). The working assumption is that for Jews the timing of immigration to Israel has less impact on family-related behaviour than the region of origin and the level of religious observance, as a result of two main factors. Firstly, for many women the incorporation of societal norms and values in the socialization process occurred during their stay in their country of origin. Value orientations formed in early adulthood influence the choice of path in family formation (Lesthaeghe and Surkyn 2006) and remain relatively persistent throughout the individual's lifespan (Inglehart and Baker 2000). Secondly, some of the immigrant women completed their childbearing abroad, and hence their completed fertility resembles that of their country of origin more than that of the country of destination.

\subsection{Data}

The main data sources are the Population Register of vital statistics from 1949 onwards, published annually in the Statistical Abstract of Israel; Social Survey data collected annually since 2002 by the Israel Central Bureau of Statistics; Israel national survey data of the Guttman Center (former Israel Institute of Applied Social Research, various years); and cross-national survey data of the International Social Survey Programme (ISSP) (various years), European Social Survey (ESS) 2002 and 2008, and World Values Survey (WVS) 2001 (See Data Appendix). In all of the above surveys the sample represents the adult population of Israel.

The advantage of using cross-sectional time series survey data from the same source is that the context-related distortions can be detected and neutralized. The 
advantage of using surveys conducted at the same point of time from various sources is that by comparing the results one can cross-validate the quality of the data from these sources (Beckers 2010). By implementing these two types of survey data in the analysis the current research benefits from the advantages of both.

\subsection{Methods and procedure}

In order to clarify the issue of social compositional effects on family attitudes and behaviour, as a starting point the overall attitudinal or behavioural change will be examined. Then the question will be addressed of whether the overall change (if it exists) is due to a change in each ethno-religious group or is merely an outcome of the changing weight of these various groups in the total population. Breaking up the data on marriage and fertility behaviour by ethnic and religious parameters will allow answering this question. Thus the groups in which the traditionalism/modernism paradox exists will be identified. The groups which are characterized by a consistent traditionalism or modernism pattern will also be detected. Signs of transition on a group level might exist, even though on an aggregate (country) level these might be obscured.

The last but not least concern relates to ideational change. Which values are most important to test for change? The theory of the SDT relies on Inglehart's postmaterialism (Lesthaeghe 2010), supported empirically by the World Values Survey (WVS) data. The concept of emancipative values, which is a further elaboration of Inglehart's original self-expression values, proposed later by Welzel and Inglehart (2010) and Welzel (2012), relies on similar theoretical premises and the same data source. Emancipative values comprise an index from 0 to 1 of value orientation that supports gender equality, expression of people's voice, personal autonomy, and lifestyle tolerance. The index was constructed using formative logic. It summarizes conceptually complementing elements of liberating value orientation (Welzel 2012). A change in these emancipative values can primarily and most effectively show the ideational change relevant to the SDT in any given society. Therefore in the current research the ideational change will be tested using the concept of emancipative values.

\section{Results and discussion}

\subsection{Attitude and value change in Israel}

According to the SDT theory, ideational change escorts behavioural change. This generational value change is of crucial importance since it is a necessary (but not 
sufficient) condition of the SDT (Lesthaeghe 2010). In order to track this change the time dimension needs to be accounted for. One way of showing change over time when only cross-sectional survey data are available is by testing the effect of year of birth on value orientation. If systematic differences in attitudes and values between younger and older respondents are found, the phenomenon can be regarded as a societal value change.

Indeed, emancipative value change has taken place in Israel, as shown in Figure 2. Two important trends can be distinguished: firstly, some evidence of ideational change is seen from the higher emancipative value orientation of the younger as compared to the older Jewish respondents. Secondly, a generational change in attitudes has occurred on the aggregate level among Jewish Israelis, but not among the Arabs (the vast majority of whom are Moslems).

The emancipative value orientation in Israel was calculated on the basis of nine items of the WVS, grouped into lifestyle tolerance (acceptance of homosexuality, divorce, and abortion); personal autonomy (imagination and independence as important child qualities, and non-indication of obedience as such a quality); and people's voice (priority given to protecting freedom of speech, to giving people more say in important government decisions, and giving people more say about how things are done at their jobs and in their communities). The score 0 indicates total absence of emancipative value orientation and total deference to authority, while the score 1 indicates absolute expression of emancipative value orientation and a quest for freedom and equality (Welzel 2012). 
Figure 2: Emancipative value orientation among Jews and Arabs in Israel in 2001 by year of birth

\section{Jews}

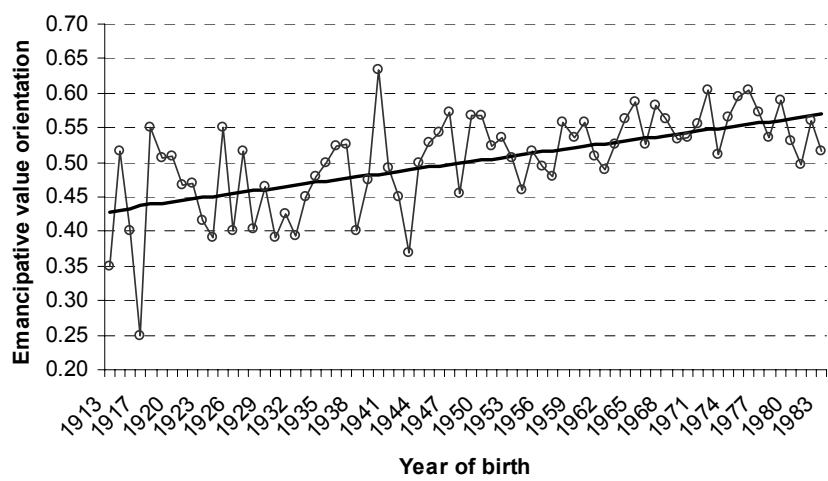

\section{Arabs}

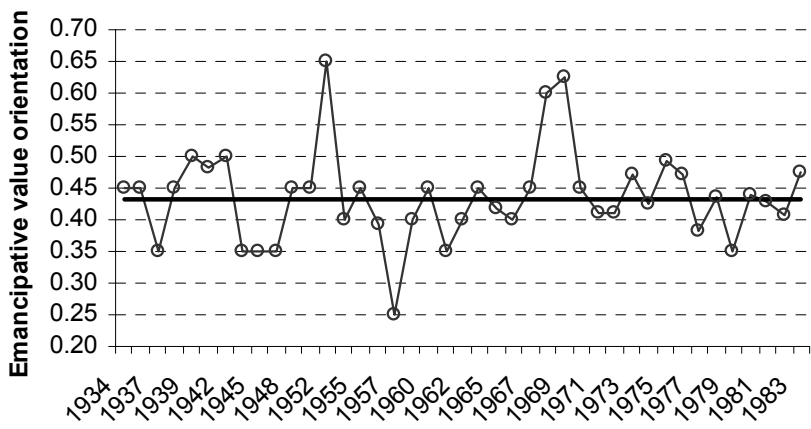

Year of birth

Notes: Regression estimates for Jews $(N=1,002)$ were based on $y^{\prime}=0.605-0.002 * A g e ; p<0.001$

Regression estimates for Arabs $(\mathrm{N}=151)$ are $\mathrm{y}^{\prime}=0.433$; effect of age non-significant

Source: calculated from the WVS (2001) data provided by Christian Welzel

Gender equality was not measured in the WVS 2001 in Israel, and therefore was not included in the index. Fortunately, however, attitude change on issues related to gender roles and lifestyles can be presented using complementary data from another 
source, ISSP 2002; as follows. Analysis of variance shows a statistically significant effect of age on attitudes, and thus confirms that generational change has taken place. Older people tend to agree more that: "people without children lead empty lives", "bad marriage is better than no marriage", "it is better to marry, if people want children", "household satisfies as much as paid job", "work is NOT the best way for women to achieve independence", $(\mathrm{p}<0.05)$; "what women really want is home and children", and "divorce is NOT the best solution when marriage faces problems" $(p<0.10)$ (calculated from ISSP data 2002).

Another important notion is that the scope of value change differed between religious and non-religious groups, with the religious groups displaying more traditional value orientation and tending not to change it. The effect of religiosity was found statistically significant $(\mathrm{p}<0.05)$ in analysis of variance within all the examined attitudes, except for the item "bad marriage is better than no marriage", where no significant difference was found among people of various levels of religiosity (ISSP data 2002).

These findings support the first two research hypotheses. Overall value orientation among the Jewish respondents has changed in the predicted direction of less traditional and more liberal attitudes toward family and gender roles. Both of the above data sources provide evidence of generational value change on the aggregate level. On the group level, primarily and most profoundly, the young non-religious Jewish groups lead this change. There is also evidence that the change has occurred among some of the religious groups, although their values can be characterized as rather traditional. Most religious groups, as expected, were marked by conservative worldviews. No significant value change was found among the Moslems.

As some signs of ideational change were found to be present among certain groups, the next step would be to analyse whether behavioural change is present as well. The following sections relate to what happens in the domains of living arrangements and childbearing. The main question to be answered is: have marital and fertility transitions taken place in Israel?

\subsection{Marital transition in Israel}

\subsubsection{Marital behaviour and attitudes}

Attitudes to marriage in Israel are interesting to inspect in order to understand marital behaviour. For instance, $73 \%$ of Jewish respondents stated that a religious wedding is important to them, and $64 \%$ stated that a couple that wants children must be married 
(Social Survey 2009). The latter statement shows a more permissive trend compared to 1994, when 74\% shared that view (ISSP 1994).

Not surprisingly, inasmuch as 94\% of Israelis aged 45-49 in 2008 had been married at least once in the course of their life (ICBS, Statistical Abstract of Israel 2010), marriage in Israel can still be regarded as close to universal. Among European countries, only in Bulgaria and the Czech Republic had the percentage of ever-married by age 50 exceeded $90 \%$ for the birth cohort of 1965 (Sobotka and Toulemon 2008). Israel lags behind Europe, where universal marriage has ended.

Yet a marital transition has unfolded in Israel since the 1970s. Despite the fact that there has been a mass postponement of marriage among the Jewish population, there is no evidence of marked postponement among the Moslems. The mean age of Jewish women at first marriage has risen from 21.8 in 1970 to 25.7 in 2009, and of Moslem women from 20.1 to 21.4 (ICBS, Statistical Abstract of Israel, various years). This increase of four years for Jews in Israel corresponds with European transitional patterns. The mean age at first marriage of Jewish women is similar to that in Eastern and Central Europe. For instance, in 2005 in Israel (Jewish women), Romania, and Poland the mean age at first marriage was 25.4 years, in Bulgaria 25.8 years, in the Czech Republic 26.4, and in Hungary 26.7. The Jewish Israeli mean age is higher than the Russian (23.3) or the Lithuanian (25.0) but much lower than the Dutch (29.1), Spanish (29.3), French (29.4), and Swedish (31.5) (Sobotka and Toulemon 2008).

The percentage of never-married has increased over the last two decades in each age group among the Jewish women. Among those aged 20-24 the share of nevermarried reached $78.4 \%$ in 2009 , and among those aged $25-29$ it exceeded $45 \%$ (ICBS, Statistical Abstract of Israel 2011, Table 2.20). The most drastic postponement of marriage is found within the latter age group: between 1994 and 2009 the rise in the share of never-married of this age exceeded 23 percentage points (Israel, Statistical Abstract of Israel, various years, Tables 2.19, 2.20). Postponement is also evident among women aged 30-34: in 1994 the share of never-married comprised approximately $10 \%$, while fifteen years later their share increased to approximately $20 \%$.

However, postponement of marriage is not uniform; some Jewish women continue to marry in their early twenties while others wait until their thirties. The level of religiosity plays a key role here. The Ultra Orthodox women do not show signs of marital transition at all, while the less religious show signs to different degrees. The scope of postponement of marriage during the last decade by level of religiosity is shown in Table 1. The secular group is pioneering, with almost 30 percentage points difference between 1968 and 2009 in the share of single women aged 20-29. The alternatives to marriage for these non-religious women are non-familial living arrangement, living with a partner, and residing with parents (Einhorn 2005). 
Table 1: Percentage of never married Jewish women aged 20-29 by the level of religiosity in 1968-2009

\begin{tabular}{|c|c|c|c|c|c|c|c|c|}
\hline $\begin{array}{l}\text { Religious } \\
\text { identity (as } \\
\text { measured by } \\
\text { The Guttman } \\
\text { Center) }\end{array}$ & 1968-1969 & 1986-1988 & 1991- 1992 & $\begin{array}{l}\text { Religious } \\
\text { identity (as } \\
\text { measured by } \\
\text { the Social } \\
\text { Survey) }\end{array}$ & 2002-2003 & 2004-2005 & 2006-2007 & 2008-2009 \\
\hline \multirow{2}{*}{ Religious } & \multirow{2}{*}{38} & \multirow{2}{*}{39} & \multirow{2}{*}{35} & Ultra Orthodox & 20 & 22 & 18 & 29 \\
\hline & & & & Religious & 43 & 47 & 50 & 53 \\
\hline \multirow{2}{*}{ Traditional } & \multirow{2}{*}{33} & \multirow{2}{*}{51} & \multirow{2}{*}{46} & $\begin{array}{l}\text { Traditional } \\
\text { religious }\end{array}$ & 50 & 55 & 66 & 62 \\
\hline & & & & $\begin{array}{l}\text { Traditional non- } \\
\text { religious }\end{array}$ & 63 & 64 & 63 & 73 \\
\hline Non religious & 49 & 58 & 63 & Secular & 69 & 75 & 77 & 78 \\
\hline Total & 38 & 50 & 49 & Total & 59 & 61 & 62 & 65 \\
\hline $\mathrm{N}$ & 525 & 498 & 321 & $\mathrm{~N}$ & 1,364 & 1,443 & 1,308 & 1,252 \\
\hline
\end{tabular}

Notes: The samples are pooled from the same source because of a non-sufficient number of observations in a single survey; in some surveys the distinction was made between single, married, widowed, and divorced. Italics indicate a small number of respondents in the respective cell; caution is needed in interpreting these data.

Source: calculated from the Guttman Center data 1968-1992 and Social Survey data 2002-2009

\subsubsection{Factors impeding marital transition}

Besides religiosity, another characteristic severely impedes the marital transition in Israel. Contrary to the West, in Israel civil marriages do not exist as such. This institutional constraint on the marriage market is highly problematic from the liberal point of view (Sapir and Statman 2009) since it limits individual freedoms. The authority to certify marriage and divorce lies in hands of each religious community. That is, Orthodox rabbinical courts grant certificates to Jews, Sharia courts grant certificates to Moslems and Druze, and authorized officiating ministers grant certificates to Christians. Marriages and divorces performed abroad or 'alternative marriages' performed in Israel are not included in official vital statistics (ICBS, Statistical Abstract of Israel 2011). They are, however, acknowledged and registered at the Population Register for taxation, health insurance, and economic benefits purposes (Israel, Ministry of Interior 2011).

Marital transition also implies increasing divorce rates. Although they are an important feature of the SDT, it is difficult to draw direct conclusions as to why they rise so slowly in Israel. No doubt the status quo in the sphere of marriage and divorce in Israel complicates the procedure of marriage dissolution. Despite a certain rise, divorce rates in Israel remain low and range from 1.7 (per 1,000 persons) in the 1950s to 1.9 in 
2009 (ICBS, Statistical Abstract of Israel 2011, Table 3.1). Israeli attitudes toward divorce as a solution to marriage problems are similar to those in Europe (ISSP 2002). Consequently, the interpretation of Israeli divorce trends requires caution.

Rising liberal aspirations might be another reaction to the legislative constraint. The secular groups in the population object to the fact that the only legal way of marrying in Israel is through a religious ceremony in the Orthodox Rabbinate (Gavison 2003; Liebman and Don-Yehiya 1984). Their answer might be unmarried cohabitation and non-marital procreation inside these unions, marrying abroad, or marrying in Israel in alternative ways. These implications of the situation in the marriage and divorce market need to be further investigated.

\subsubsection{Alternatives to marriage}

Cohabitation as an alternative to a conventional marriage form of union is accepted to various degrees among the Jewish Israelis, but not among the Moslem Israelis, for whom this option does not exist as normative (Einhorn 2005). Younger Israelis, similarly to Europeans, support cohabitation to a significantly greater extent than the older Israelis (Malnar 1999). This is not surprising, since the younger cohorts are less traditional, emphasize survival values less, and show higher levels of self-expression values (Inglehart and Baker 2000).

Interestingly, attitudes toward cohabitation have been positive only among the non-religious and traditional Jews (Table 2). Only these groups support unmarried cohabitation, which is defined as a substitute or alternative to marriage (Heuveline and Timberlake 2004), and pre-marital cohabitation, which has greatly increased over the last decade among these groups only. Over this last decade both religious groups became less tolerant of cohabitation, that is, they seem to progress in the opposite direction to the SDT.

Looking at the total Jewish population, compositional effects can be clearly observed: the support for pre-marital cohabitation drops from $63 \%$ in 1994 to $62 \%$ in 2002 , and for unmarried cohabitation from $61 \%$ to $57 \%$ (see Table 2). Even though the support for these behaviours has risen among the non-religious and traditional Jews, the increasing weight of the religious groups in the total population (due to their extremely high birth rates) obscures the secular-liberal attitudes toward cohabitation in Israel. That is, the population composition is a strong enough factor to conceal the obvious transitional trend of the non-religious and traditional groups. This notion is of tremendous importance for future monitoring of Jewish demographic trends. 
Table 2: Attitudes among Jewish Israelis toward unmarried and pre-marital cohabitation by the level of religious observance

\begin{tabular}{llcccc}
\hline $\begin{array}{l}\text { Level of religious } \\
\text { observance }\end{array}$ & $\begin{array}{l}\mathbf{1 9 9 4} \\
\mathbf{N = 1 , 2 7 8 )} \\
\text { Percentage of approval of } \\
\text { Unmarried } \\
\text { cohabitation }\end{array}$ & $\begin{array}{c}\text { Pre-marital } \\
\text { cohabitation }\end{array}$ & $\begin{array}{c}\text { Pre-marital sexual } \\
\text { relations }\end{array}$ & $\begin{array}{c}\text { Unmarried } \\
\text { cohabitation }\end{array}$ & $\begin{array}{c}\text { Pre-marital } \\
\text { cohabitation }\end{array}$ \\
\hline Very religious & 11 & 8 & 0 & 8 & 3 \\
Religious & 28 & 25 & 15 & 26 & 22 \\
Traditional & 53 & 59 & 55 & 58 & 67 \\
Non-religious & 70 & 73 & 77 & 77 & 83 \\
Total & $\mathbf{6 1}$ & $\mathbf{6 3}$ & $\mathbf{6 5}$ & $\mathbf{5 7}$ & $\mathbf{6 2}$ \\
\hline
\end{tabular}

Source: calculated from ISSP data 1994, 2002

In contrast to the relatively positive attitudes toward cohabitation in Israel, the behavioural pattern differs greatly. The absolute levels of $3 \%-4 \%$ of adult Jewish population currently cohabiting can be considered as remarkably low, in spite of a slight rise during the last two decades (ISSP 1994-2007).

Overall, the spread of ever-experienced unmarried cohabitation among the younger Jewish cohorts is greater than among the older (Figure 3). An exception is the youngest age group of 20-24, who might have not yet been fully exposed to this alternative. The compulsory army service in the Israel Defence Force (until the age of 20 for women and 21 for men) might cause this delay. An additional explanation for the seeming decline in ever-experienced unmarried cohabitation among young people below the age of 35 is, once again, the population composition effect. Among the younger cohorts there are more people who define themselves as religious. Therefore, their behavioural pattern dominates the trend among all the young.

If the data are broken up by level of religiosity, there is an increase in everexperienced unmarried cohabitation among the non-religious and traditional Jews. Moreover, as a prelude to marriage, pre-marital cohabitation is much more widespread than unmarried cohabitation. Pre-marital cohabitation leads by some 20-30 percentage points (at maximum) compared to unmarried cohabitation. This behavioural trend corresponds with moral norms and attitudes towards such types of behaviours. The cohort of non-religious and traditional Jews born in 1968-72 crossed the 50\% threshold of ever-experienced unmarried cohabitation (ESS 2002). So far the following cohorts have not reached this threshold. The question as to whether the population composition will ever allow such thresholds to be reached in future remains open. 
Figure 3: Ever-experienced unmarried cohabitation among Jews in Israel in 1994, 2002 and 2008

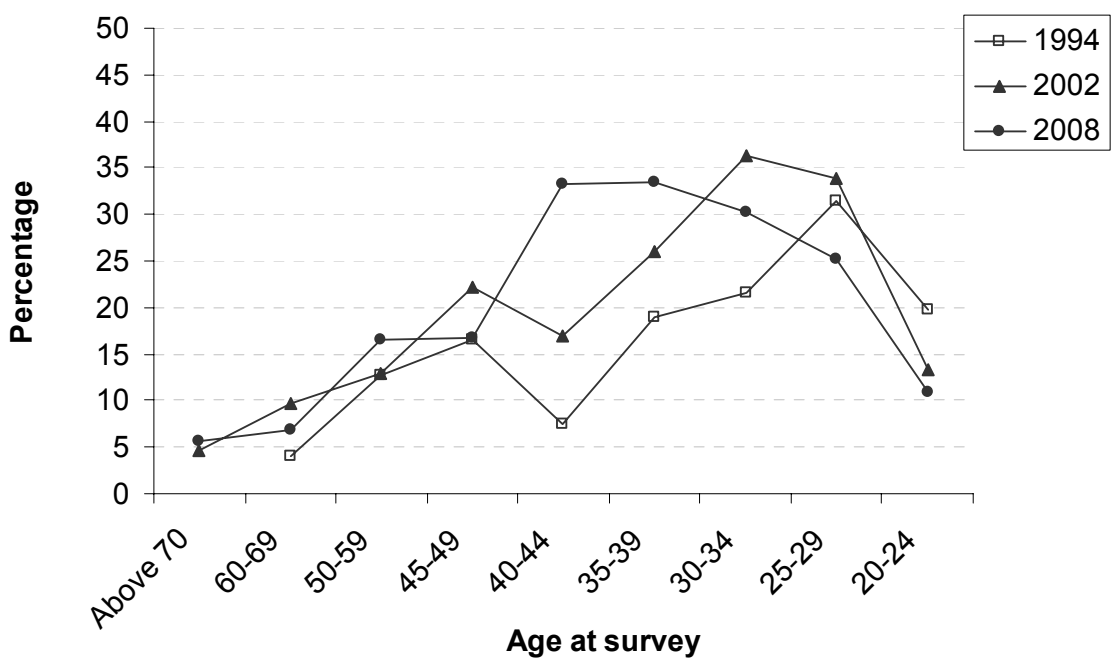

Note: the item reads 'have you ever lived with a partner whom you eventually did not marry?' Sources: calculated from ISSP 1994; ESS 2002,2008 data

Nevertheless, in Israel in 2008 the $11 \%$ of currently cohabiting women under the age of 29 is similar to some of Europe, although generally much lower: about $10 \%$ reported cohabitation in Poland and Portugal, $11 \%$ in Slovakia, 13\% in Spain, 17\% in Bulgaria, 21\% in Germany and Denmark, 23\% in Hungary, 25\% in Norway and France, $30 \%$ in Finland, 33\% in the Netherlands, and 36\% in Sweden (data of ESS 2008).

To sum up the trends in marital transition: religious women do not postpone marriage and do not participate in alternative living arrangements. They display consistent patterns of traditionalism per se, so the SDT is not a relevant term for describing their attitudes and behaviour. In contrast, groups who observe religious tradition to a lesser extent do postpone their marriage to various degrees, accept alternative living arrangements as a norm, and cohabit more frequently. They appear to experience a Second Demographic Transition during which the concept of family is redefined (Lesthaeghe 2010). 


\subsection{Fertility transition in Israel}

\subsubsection{Postponement of childbearing}

The trends in fertility transition resemble those of marital transition: the same groups show similar patterns of postponement in childbearing. On the aggregate level Jews in Israel postpone births, as the figures on age-specific fertility rates in a cross-temporal perspective show. The timing of the onset of postponement is important: while in 1993 the majority of births occurred at ages 25-29, by 2010 Jewish women of various ethnic origins have completed the shift toward ages 30-34 (ICBS, Statistical Abstract of Israel, various years). However, there was no fertility transition whatsoever found among the Moslems, whose main childbearing ages remained 15-24. Moslem fertility levels were still remarkably high, although these lessened during the last decades.

Figure 4 illustrates postponement of births among Israel-born Jewish women, which is typical of fertility transition. A similar picture can be observed among the rest of the ethnic groups. An outstanding case is women born in the former USSR: although their fertility regimes resembled the rest of the ethnic groups, the rates were only half as high. In Israel no group has shown below replacement fertility so far, except these women immigrants from the former USSR.

\section{Figure 4: Age-specific fertility rates of Israel born Jewish women in 1993-2010}

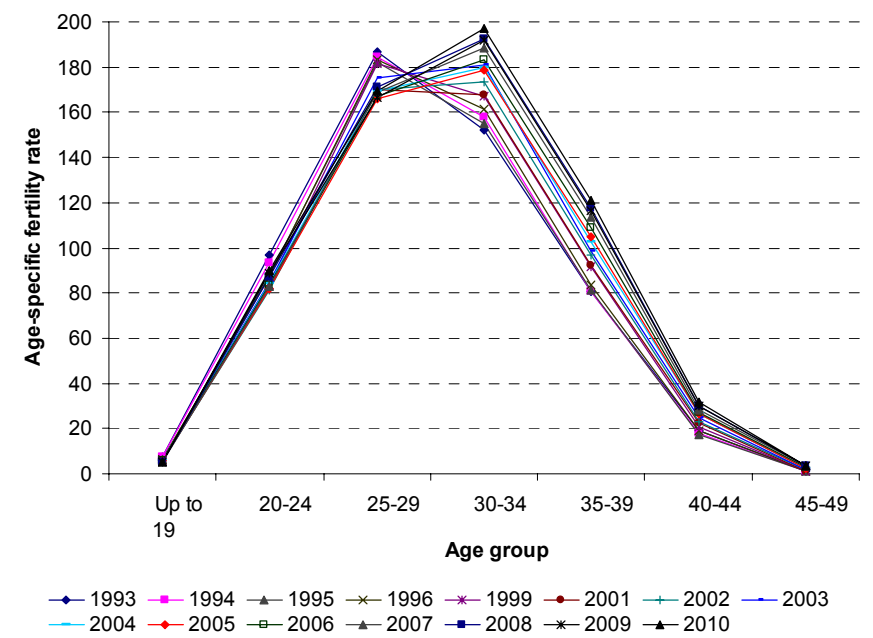

Source: calculated from the ICBS, Statistical Abstract of Israel data, various years 
Jewish fertility is most interesting to analyse by level of religious observance. In 2009 only $2 \%$ of secular women gave birth before they were 25 years of age; $76 \%$ postponed the first birth in the age group 25-29; and 38\% still remained childless at 3034 (calculated from the Social Survey 2009 data). This postponement of births to late childbearing ages is similar to the pattern in most European post-transitional countries. However, the timing of childbearing among the most religious groups was different: $28 \%$ of the religious and $32 \%$ of the Ultra Orthodox gave birth before the age of 24 (ibid). Therefore, when speaking about fertility transition in Israel, only the secular Jewish women fully fit the criteria of the SDT. Traditional women are on their way to approaching the thresholds and are strong candidates for the SDT.

The fertility transition aligns with the marital: secular and traditional Jewish women postpone their marriage and childbearing until their thirties and further. This trend is definitely non-traditional and contradicts conventional familial norms of early marriage and early childbearing. Does this postponement of childbearing among the Jewish secular and traditional women end in ultimate childlessness, or do they manage to recuperate and eventually compensate for all the delayed births? Completed fertility, which is analysed in the next section, sheds light on this question.

\subsubsection{Completed fertility in Israel}

Analysis of completed cohort fertility examines the historic fertility of women who have already completed their reproductive careers. It shows fertility of real (as opposed to hypothetical or 'synthetic') cohorts of women, and is simple to interpret since it indicates the actual number of children per woman. It is most accurate in demonstrating the level of fertility for a given cohort because it embodies the tempo effects by accounting for recuperation of delayed births. Thus, it neutralizes the tempo distortions

of the period measure of total fertility (Bongaarts and Feeney 1998). Figure 5 presents completed cohort total fertility rates in Israel of women born in 1932-68, by religious affiliation, level of religiosity, and ethnic origin.

The completed fertility rates of Ultra Orthodox Jews and Moslems are the highest; for the Jews the rates decline as the level of religious observance decreases. Ultra Orthodox Jews display an opposite pattern to the SDT of rising fertility over the last decades. Religious Jews and Moslems displayed high levels of fertility. Although their completed fertility is gradually decreasing, the levels were still tremendously high in 2008, even among the cohort of women aged 40-44 who were about to complete their reproductive career. The fertility of secular women of European origin born before 1964 was below the replacement level: completed cohort total fertility rates of these women comprised 2.0 children per woman, while secular women born in the former 
Bystrov: The second demographic transition in Israel

USSR showed the lowest completed fertility of 1.7 children per woman (data of Social Survey 2009). Thus, research hypotheses 1 and 2 are supported.

Figure 5: Completed cohort fertility rates of Israeli women born in 1932-68 by religious affiliation, religious observance, and ethnic origin
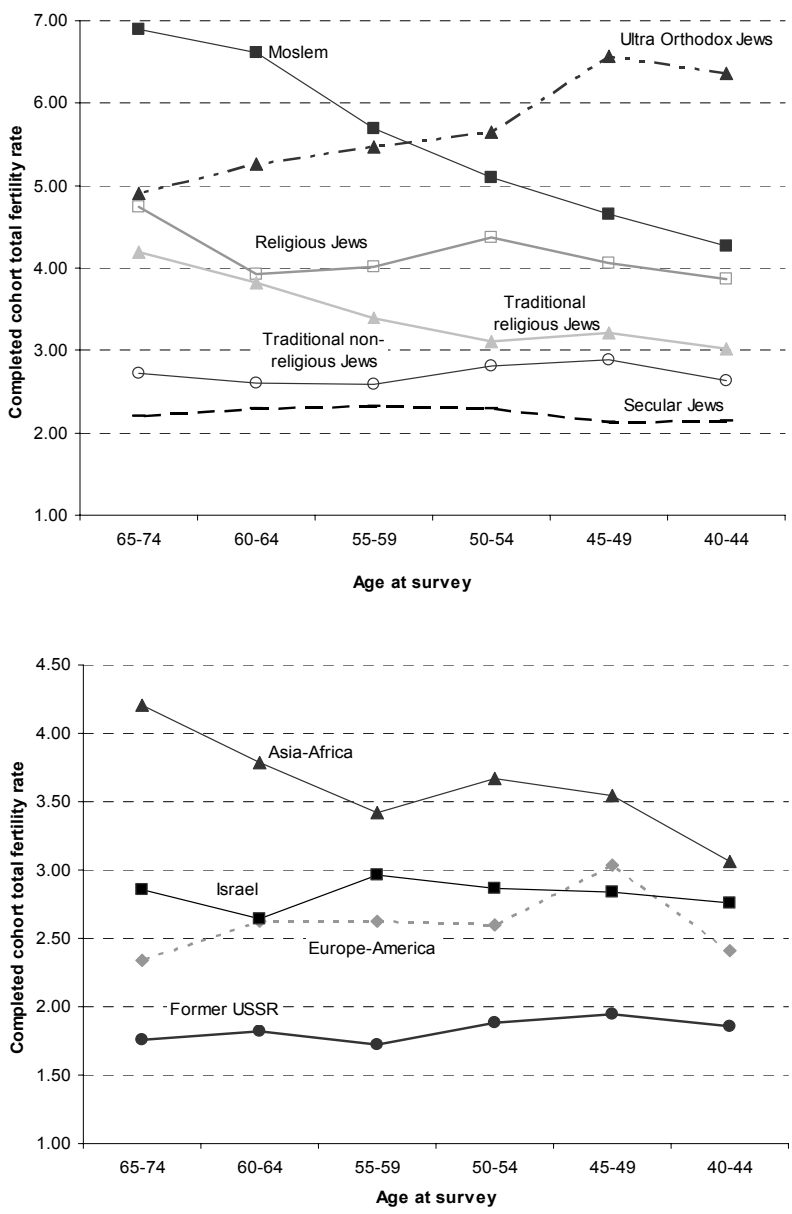

Note: grouping by ethnic origin is without Ultra Orthodox

Source: calculated from pooled data of Social Survey 2006, 2007, 2008 
The completed fertility can be portrayed by other means as well. For example, parity progression ratios show the percentage of women of a given parity who have given birth to at least one additional child. In other words, parity progression ratios from 0 to 1 indicate the share of women who progress from the state of childlessness to the state of being a mother of one child, and so on. Figure 6 demonstrates the variety of fertility regimes in Israel. For example, after having one child women from the former USSR exhibited an extremely sharp decline in progression rates towards the second child. Such an intriguing pattern can be referred to as "stopping at one" (at most) behaviour (Hosseini-Chavoshi et al. 2006). For secular Jews it was "stopping at three" behaviour.

Ultra-Orthodox and Moslem women displayed extreme fertility regimes, which can be characterised as "non-stopping even at four". Their parity progression ratios remained relatively stable at very high levels across almost all birth orders (more than $90 \%$ until birth order four and more than $80 \%$ for births of higher order). In other words, women who gave birth to four children did not stop at all and were likely to progress to five, six, seven, and more children.

These heterogeneous fertility patterns have been studied previously: Friedlander and Feldmann (1993), for instance, argued that the heterogeneity of Israel's population disguises fertility declines of some sub-groups which transit toward the European low fertility pattern. Using a period measure of total fertility in 1983-85, the authors showed that the group of European ethnicity (immigrants from the European continent or Israeli-born descendants of such immigrants) displayed below replacement fertility at the beginning of the 1980s. However, since these authors have calculated a period measure, it could have been distorted due to the tempo effect of postponement of childbearing. The recuperation that has occurred afterwards at late childbearing ages could not have been captured by Friedlander and Feldmann's period measure. It is, however, taken into account within the completed fertility analysis performed in this paper. 
Bystrov: The second demographic transition in Israel

Figure 6: Parity progression ratios of Israeli women born in 1932-68 by religious affiliation, religious observance, and ethnic origin
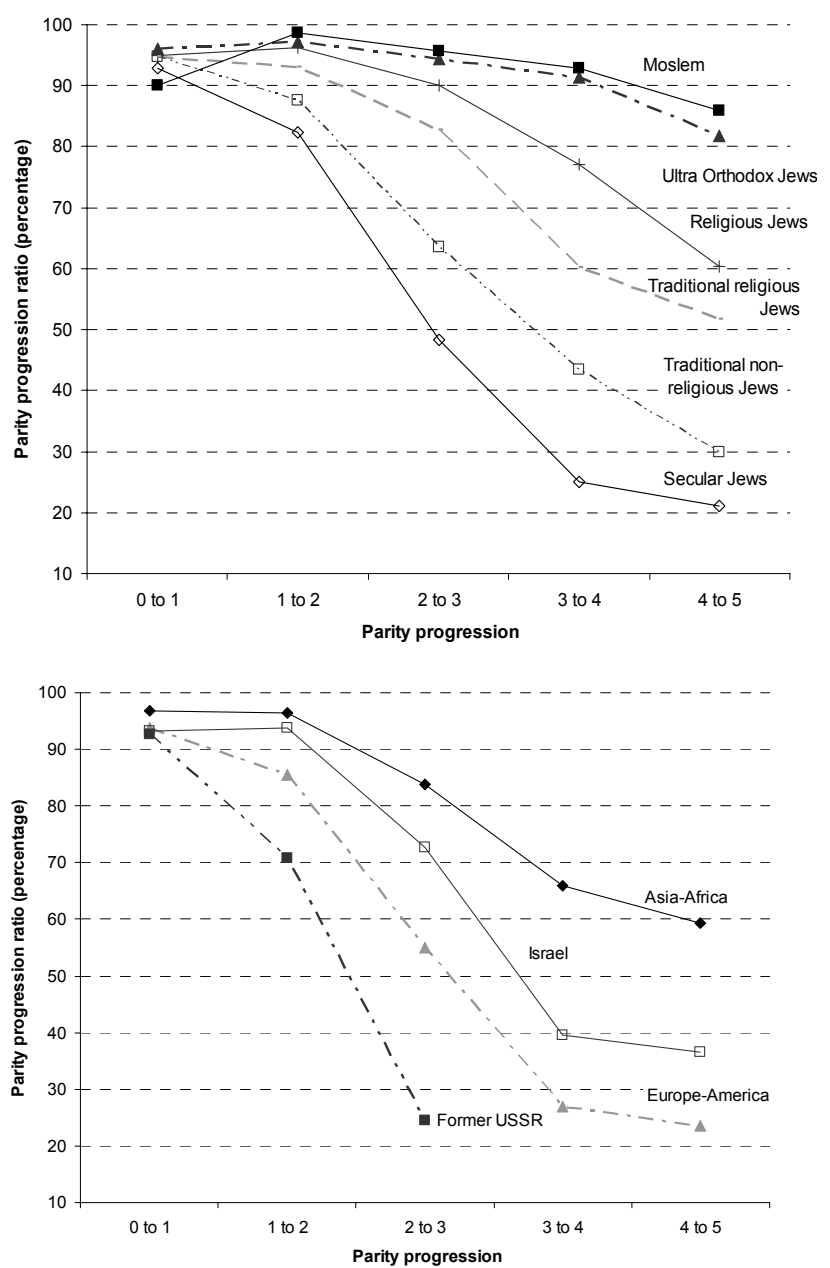

Notes: The number of children at parities higher than 7 is documented in the Social Survey as 7+. Therefore, for high-fertility subpopulations the calculations were based on 8 as the maximal parity. This may lead to some underestimation of completed fertility among these subpopulations. Grouping by ethnic origin is without Ultra Orthodox. Source: calculated from pooled data of Social Survey 2006, 2007, 2008

Comparison with European countries shows that Israeli women differ noticeably in their fertility profiles. In the EU-27 completed cohort the fertility of women born in 
1968 was 1.74 children per woman, ranging from the low of 1.49 in Germany to the high of 2.22 in Cyprus (VID 2010). Only two groups in Israel closely resemble Europeans: secular Jewish women are placed at the upper threshold of European fertility while women born in the former USSR fall close to the European average.

In fact Israelis, unlike many Europeans in the first decade of the $21^{\text {st }}$ century, still maintain fertility above replacement level. There are no signs of low-lowest fertility. How are these levels maintained if childbearing is postponed? The answer is recuperation of births at late childbearing ages. Figure 7 demonstrates the rising fertility over the last decades of Jewish women born in Israel aged 35-39 and 40-44. Intriguingly, during these late childbearing ages, the fertility rates of Jewish women born in Israel outnumber the fertility rate of women born in the former USSR at its peak. This fact stresses the magnitude of the phenomenon of late childbearing.

\section{Figure 7: Rising fertility at late childbearing ages among Israel-born Jewish} women 1955-2010

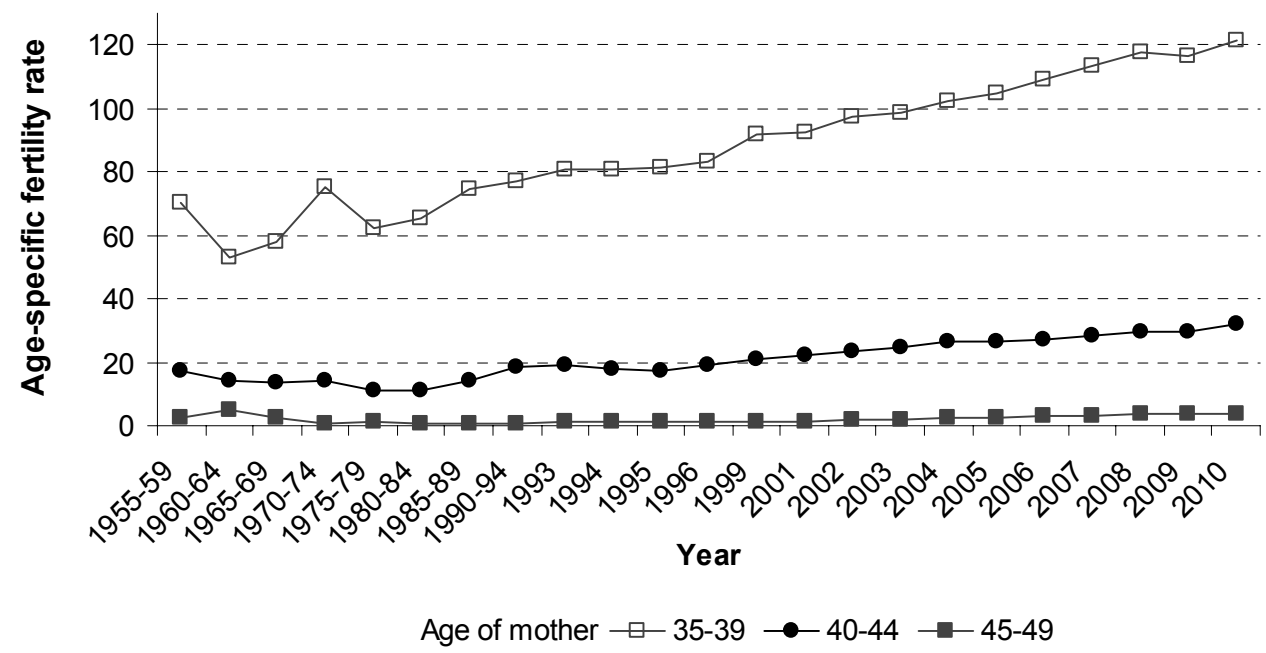

Source: edited from the ICBS, Statistical Abstract of Israel, various years, Tables 3.12, 3.13 and 3.14

\subsubsection{Contraception behaviour}

To complete the discussion of fertility transition, an additional feature of the SDT needs to be addressed: the use of modern contraception. Efficient contraception is one 
of the dimensions in which countries differ. The majority in Israel can be characterized as progressing toward European standards. In the late 1980s the intrauterine device (IUD) was the most frequently used contraceptive method among Jewish women aged 18-39 and the pill the second most prevalent (Okun 1997, 2000), but later on this picture changed. According to the survey of the Israel Association for the Advancement of Women's Health (2003), the pill became the most frequently used contraception among Jewish women aged 25-44: $26 \%$ used the pill and another $18 \%$ used the IUD. Therefore in this respect Israeli Jewish women have passed the first phase of the SDT (Sobotka et al. 2003).

Abortion in Israel is used mainly as a method of correction and is subject to the approval of governmental Committees for Termination of Pregnancy. Approximately $98 \%$ of cases have been approved annually since 2000 . The rates of legal abortion decreased from about 153 per 1,000 live births in 1987 to 117 in 2010 (ICBS, Statistical Abstract of Israel 2010, Table 3.20), and these are comparable with the lowest in Europe. Only the Federal Republic of Germany, with 143 in 1985, and the Netherlands, with 107 in 1984 (van de Kaa 1987), ranked lower. In 2009 in the Netherlands, the country with the lowest abortion rates among the developed countries, the abortion ratio was 153 per 1,000 live births (about $12.5 \%$ of these were for women residents of other states who had travelled to the Netherlands especially for this purpose) (Netherlands, Inspection for Healthcare 2010).

\subsubsection{Implications of fertility transition}

As a consequence of postponement of childbearing until very late ages, three main demographic outcomes can be observed: firstly, the percentage of multiple births rises dramatically after the age of 45 due to assisted reproduction; secondly, extremely low levels of eventual childlessness are found because of the almost complete compensation for all the delayed births; and, thirdly, out-of-wedlock fertility at those ages rises as well. As a result the mother profile in the society changes tremendously. Motherhood is no longer the prerogative of married young women in their twenties or thirties.

Since some women cannot give birth at late childbearing ages without assisted reproduction, the likelihood of multiple births increases. The incidence of giving birth to several newborns is much higher at late ages than at young ages when such medical intervention is less frequent. For instance, in 2008 approximately $30 \%$ of births to women over 45 involved more than one newborn (Figure 8). In the future this proportion could rise even more. This interesting phenomenon is a direct outcome of the postponement and recuperation of childbearing. Such developments can be expected 
in post-transitional societies, where the timing of childbearing is shifted and subjected to various individual life-goals.

Figure 8: Proportion of multiple births among Jewish women in Israel in 2002-08

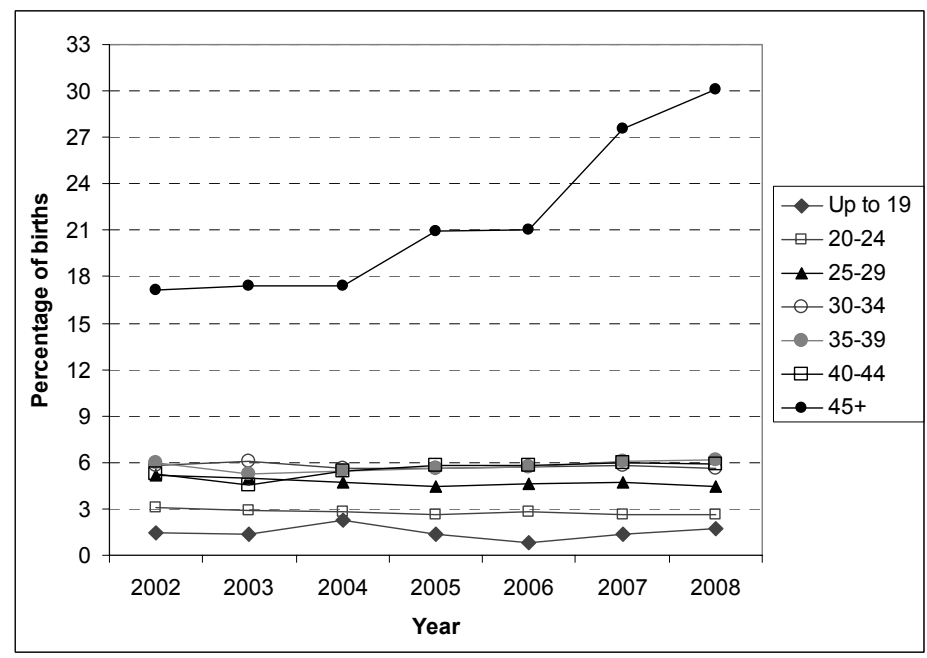

Source: edited from the ICBS, Statistical Abstract of Israel, various years, Tables 3.17 and 3.18

Jewish Israeli women seem to catch up with childbearing despite the postponement. Ultimate childlessness is relatively low among all the Jewish women, regardless of the level of their religiosity. For instance, among women born before 1959 who had recently completed their childbearing career, the highest ultimate childlessness was $7 \%$ for secular women, and the lowest $2 \%$ for Ultra-Orthodox women (calculated from data of Social Survey 2009). Such a phenomenon can be understood better in the light of Jewish traditional familism and affection for children, which have already been studied in depth (Fogiel-Bijauoi 2002). For instance, the fact that 61\% of Jews in 1994 and $58 \%$ in 2002 agreed with the statement "people without children lead empty lives" clearly demonstrates a preference for having children (data of ISSP 1994).

Furthermore, raising a family was found to be of the highest importance for the vast majority of Jews (data of ISSP 1994). Religiosity had a weaker impact here than in other questions regarding norms and values. The importance of having at least one child seems to affect the overall population of Israel and is stronger than the belief in 
marriage, as a rising percentage of Jewish women at late childbearing ages give birth out-of-wedlock (Figure 9).

Figure 9: Non-marital age-specific childbearing among Jewish women in 1962-2010

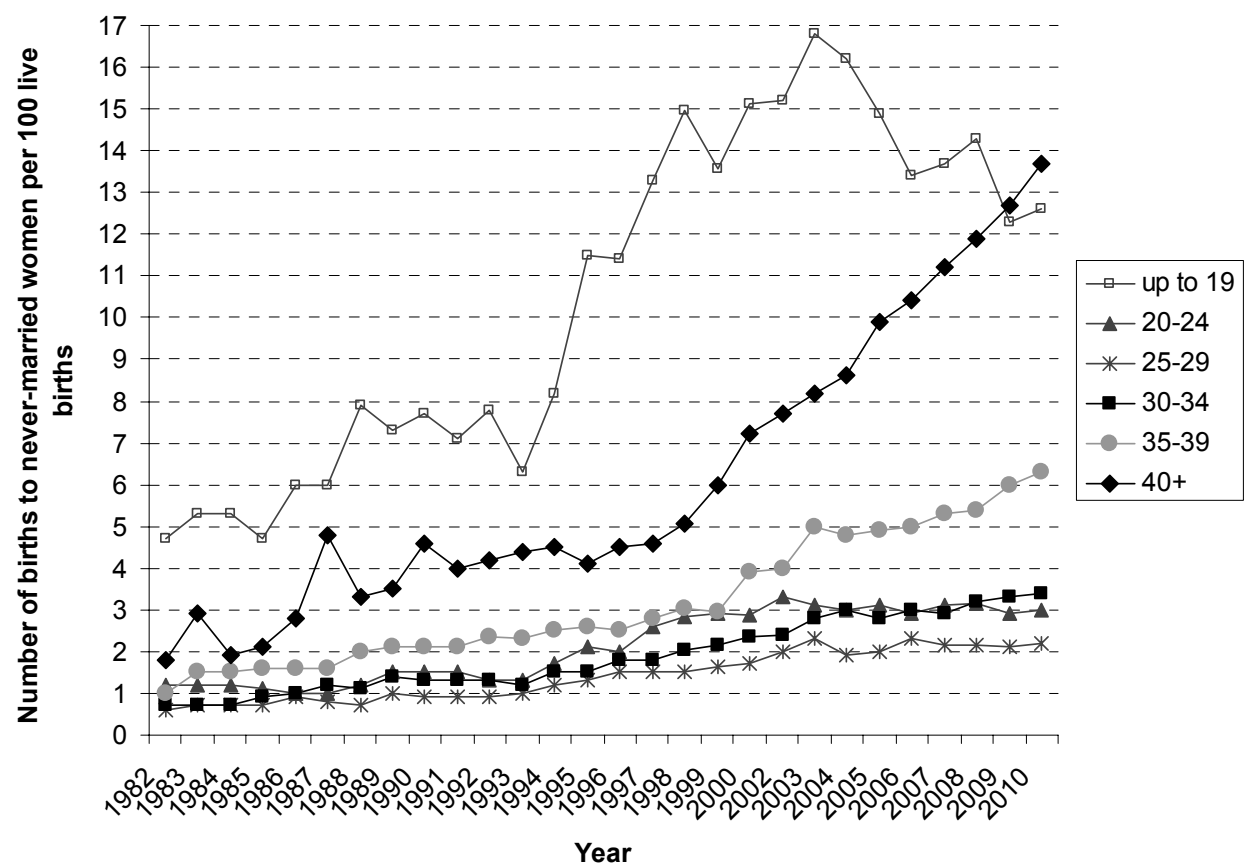

Note: Births to never-married Moslem, Druze, and Christian women are not reported in order to protect these women from possible violent outcomes of such 'a violation of family honor' (Fogiel-Bijaoui 2002: 41)

Source: edited from ICBS, Statistical Abstract of Israel, various years, Tables 3.16 and 3.17

However, non-marital childbearing is still marginal, and in 2010 constituted approximately 4\% of all births (ICBS, Statistical Abstract of Israel 2011, Table 3.17). A similar percentage of fewer than 5\% was found only in Greece and Cyprus, and these are exceptions compared to most European countries where non-marital childbearing is above 20\% (Perelli-Harris et al. 2009).

It appears that not every feature of the SDT is present in Israel. Eventual childlessness is almost non-existent and out-of-wedlock childbearing is minor, as is unmarried cohabitation. Therefore the fourth hypothesis is also supported. 
The growing heterogeneity in reproduction and changing mother profile has important implications for society in general, for the higher education system where women stay longer, and particularly for the labour market which needs to adjust to the needs of late motherhood. Flexibility, openness, and readiness to change are the key issues. The extent to which society, institutions, and the markets can successfully adjust to the newly emerging family forms and needs directly affects individual well-being.

\section{Summary and conclusions}

This study analysed recent developments in family behaviour and the underlying processes of social change in Israel. It showed that over the past two decades most of the Jewish population has experienced transition in living arrangements, marriage, and childbearing behaviours, accompanied by emancipative value change. This congruence between behavioural and ideational change corresponds with the premises of the SDT theory, and shows, using an Israeli example, that the demographic transition echoes to some extent the transition toward post-modernity.

This study also confirmed that Israeli society is highly heterogeneous in the scope and timing of its approach to the transition. SDT in Israel unfolds in a non-uniform manner. There is a clear connection between the level of religiosity by self-definition and the degree of transition along the continuum. The secular pole is in the vanguard of the SDT: the non-religious groups experienced marital and fertility transitions both on attitudinal and behavioural levels. The Ultra Orthodox pole does not seem to approach the SDT either in value orientation or in family-related behaviours. Evidently this group has not even completed the first demographic transition, at least in regards to fertility. Friedlander and Feldmann (1993) reached a similar conclusion. Secularizing trends and liberation from religious authorities seem to be crucial elements for the emergence of any significant change in family attitudes and behaviours.

Although there is no one path for the SDT which all societies must walk, core features are likely to be found in most post-transitional societies. Israel is not an exception in that respect. However, some features are country-specific. In Israel they are mainly connected to childbearing behaviours. Raising children seems to be a very strong societal value, which is also expressed at the behavioural level and is clearly indicated by compensation for delayed births, which maintains fertility above the replacement level for non-religious women, extremely low levels of ultimate childlessness, and frequent out-of-wedlock childbearing at late ages. These features, coupled with the low prevalence of unmarried cohabitation, similarly to other Mediterranean countries, imply that some traditional family norms still dominate in Israel. One reason for these norms being preserved might be that the religious 
environment in Israel enhances the religiosity of the most secular Jews and even the non-Jews who reside among them (Lazerwitz and Tabory 2002).

Moreover, Israeli marital transition takes place within conditions that differ radically from the European. As the authority to regulate personal matters, such as marriage and divorce, lies in the hands of the Orthodox institutions, this status quo has created friction between population groups that are advanced in the SDT and those which are not (Bystrov 2012). The absence of civil marriage and divorce certainly poses a serious social institutional constraint that has a long-term impact on such features of the SDT as alternative living arrangements and frequency of divorce.

One could speculate about the socio-political implications of the changing population structure of Israeli society in the long-term. Population projections show that the Ultra-Orthodox group will continue growing, given the current fertility trends. The proportion of this group could reach approximately $18 \%-21 \%$ of the total Jewish population by 2030 . The share of children will be very large: over the years the UltraOrthodox population is becoming younger. Moslems could comprise approximately $20 \%$ of the total population of Israel by 2030 (Ben Moshe 2011; Paltiel et al. 2012).

Such rapid changes in population composition affect the cultural, economic, and political arenas. From the socio-economic aspect, this implies that the young and dependent Ultra-Orthodox population cannot sustain itself without massive state support, comprised of direct payments as well as governmental expenditure on education, health, and other systems. If the increasing demand for support is not sufficiently supplied in time, the standard of living might deteriorate (Bystrov 2007; Bystrov and Soffer 2012).

Redistributive justice questions might sharpen the existing social chasms, described at the beginning of this paper. Socio-economic and political struggles between the groups that so far have not been settled might escalate further. Further studies of political and socio-cultural implications could shed light on what can be expected from the differential growth of the various population groups. The chances of progression or inhibition of the SDT among various groups need to be illuminated.

\section{Data appendix}

Statistical Abstract of Israel is published annually by the Israel Central Bureau of Statistics (see www.cbs.gov.il). Social Survey data was received from the Israel Social Data Center (ISDC) at the Hebrew University of Jerusalem. For a detailed description of Social Survey background, methods, and sampling see http://surveys.cbs.gov.il/ Survey/EngHelpTexts/Help2009.htm. For details on the Guttman Center data see: www.idi.org.il/sites/english/TheGuttmanCenterSurveys/Pages/TheGuttmanCenter.aspx. 
For details on the International Social Survey Programme data see www.issp.org, and the European Social Survey see www.europeansocialsurvey.org. Details on the World Values Survey are found at www.worldvaluesurvey.org.

\section{Acknowledgements}

Thanks are due to Tomáš Sobotka, Eugeny Andreev, and Ron Lesthaeghe for the insights and guidance provided at the initial stage of this research; and to Johannes Huinink, Tilo Beckers, Michael Feldhaus, Nate Breznau, Christian Welzel, anonymous reviewers, and the editor of Demographic Research for the helpful suggestions. The author is grateful to Christian Welzel for providing the data on emancipative values. The author is solely responsible for all the omissions and misspecifications. 


\section{References}

Anson, J. and Meir, A. (1996). Religiosity, nationalism and fertility in Israel. European Journal of Population 12(1): 1-25. doi:10.1007/BF01797163.

Arian, A. (1995). Security threatened: Surveying Israeli opinion on peace and war. Tel Aviv: Jaffee Center for Strategic Studies. doi:10.1017/CBO9780511625732.

Arian, A. (2003). Israeli Public Opinion on National Security 2003. Tel Aviv: Jaffee Center for Strategic Studies.

Arian, A. (2005). Politics in Israel: the Second Republic. Washington DC: CQ Press.

Arian, A., Ventura, R., and Philippov, M. (2008). Israeli Secularism in the Guttman Center Polls 1990 - 2008. In: The Guttman Center Articles. Jerusalem: The Israel Democracy Institute. www.idi.org.il/sites/english/TheGuttmanCenterSurv eys/Pages/GuttmanSurvey5.aspx (Retrieved 16.09.2010)

Baloush-Kleinman, V. and Sharlin, S.A. (2004).Social, economic, and attitudinal characteristics of cohabitation in Israel. Journal of Family and Economic Issues 25(2): 255-269. doi:10.1023/B:JEEI.0000023641.81143.43.

Beckers, T. (2010). Comparing Comparisons for Cross-Validation (CC-CV): A Proposal for Applied Survey Research Using the Example of Attitudes towards Economic Liberalism. In: Beckers, T., Birkelbach, K., Hagenah, J., and Rosar, U. (eds.). Komparative empirische Sozialforschung. Wiesbaden: VS Verlag für Sozialwissenschaften: 363-389. doi:10.1007/978-3-531-92472-4 14.

Ben-Moshe, E. (1989). Marriage squeeze and marriage patterns in Israel. In: Schmelz, U.O. and Della Pergola, S. (eds.) Papers in Jewish Demography. Jerusalem: The Institute of Contemporary Jewry, The Hebrew University of Jerusalem.

Ben-Moshe, E. (2011). Shinui Bemivne Veherkev Haukhlusiya Haisraelit Lefi Migzar Tarbuti-Dati Beesrim Hashanim Habaot - Vehashlakhotav Al Shuk Haavoda (Structural and compositional change in Israeli population by national and religious affiliation and its implications on the labor market). The Ministry of Industry, Trade and Labor. http://www.tamas.gov.il/NR/rdonlyres/2068BF24AFA6-4EAD-B2F7-D91D6B7699C3/0/X11605.pdf. (Retrieved 26.04.2012., Hebrew).

Berkovitch, N. (1997). Motherhood as a national mission: The construction of womanhood in the legal discourse in Israel. Women's Studies International Forum 20 (5-6): 605-619. doi:10.1016/S0277-5395(97)00055-1. 
Bongaarts, J. and Feeney, G. (1998). On the quantum and tempo of fertility. Population and Development Review 24(2): 271-291. doi:10.2307/2807974.

Bourdieu, P. (1996). On the family as a realized category. Theory, Culture and Society 13(3): 19-26. doi:10.1177/026327696013003002.

Bystrov, E. (2007). Israel bin ha-Olam ha-Mefutakh le-Olam ha-Mitpateakh (Israel between the developing and the developed worlds). Haifa: Chaikin Chair in Geostrategy, University of Haifa. (Hebrew).

Bystrov, E. (2012). Religion, demography and attitudes toward civil marriage in Israel 1969-2009. Current Sociology (forthcoming).

Bystrov, E. and Soffer, A. (2012). Israel, Demography 2012-2030: On the Way to a Religious State. Haifa: Chaikin Chair in Geostrategy, University of Haifa.

DellaPergola, S. (2009). Actual, intended, and appropriate family size among Jews in Israel. Contemporary Jewry 29(2): 127-152. doi:10.1007/s12397-009-9011-1.

Einhorn, S. (2005). Living Arrangements of Young Adults in Israel in 2000 by Demographic and Socio-Economic Characteristics. Jerusalem: The Central Bureau of Statistics. Working Paper Series17. (Hebrew).

Fogiel-Bijaoui, S. (2002). Familism, postmodernity and the state: The case of Israel. Journal of Israeli History 21(1): 38-62. doi:10.1080/13531040212331295852.

Friedlander, D. (1973). Family planning in Israel: Irrationality and ignorance. Journal of Marriage and the Family 35(1): 117-124. doi:10.2307/351104.

Friedlander, D. (1975). Mass immigration and population dynamics in Israel. Demography 12(4): 581-599. doi:10.2307/2060715.

Friedlander, D. (2002). Fertility in Israel: Is the Transition to Replacement Level in Sight? Population Bulletin of the United Nations 48-49: 403-410.

Friedlander, D. and Feldmann, C. (1993). The modern shift to below-replacement fertility: Has Israel's population joined the process? Population Studies 47(2): 295-306. doi:10.1080/0032472031000147026.

Friedlander, D. and Goldscheider, C. (1978). Immigration, Social Change and Cohort Fertility in Israel. Population Studies 32(2): 299-317. doi:10.1080/00324728. 1978.10410716.

Friedlander, D., Okun, B.S., Eisenbach, Z., and Lion Elmakias, L. (2002). Immigration, social change and assimilation: Educational attainment among birth cohorts of 
Jewish ethnic groups in Israel, 1925-29 to 1965-69. Population Studies 56(2): 135-150. doi:10.1080/00324720215923.

Friedlander, D., Okun, B.S., and Segal, S. (1999). The demographic transition then and now: processes, perspectives and analyses. Journal of Family History 24(4): 493-533. doi:10.1177/036319909902400406.

Gavison, R. (2003). Democracy and Judaism - Between Conceptual Analysis and Public Discourse. In: David, J.E. (ed.) The State of Israel: Between Judaism and Democracy. Jerusalem: The Israel Democracy Institute: 331-359.

Gottschalk, R. (1951). Personal status and religious law in Israel. The International Law Quarterly 4(4): 454-461.

Gurovich, N. and Cohen-Kastro, E. (2004). Ultra Orthodox Jews - Geographic Distribution and Demographic, Social and Economic Characteristics of the Ultra-Orthodox Jews Population in Israel: 1996- 2001. Jerusalem: Central Bureau of Statistics. (Working paper series, No. 5., Hebrew)

Heuveline, P. and Timberlake, J.M. (2004). The role of cohabitation in family formation: The United States in comparative perspective. Journal of Marriage and Family 66(5): 1214-1230. doi:10.1111/j.0022-2445.2004.00088.x.

Hosseini-Chavoshi, M., McDonald, P., and Abbasi-Shavazi, M.J. (2006). The Iranian fertility decline, 1981-1999: An application of the synthetic parity progression ratio method. Populations 61(5-6): 701-718.doi:10.3917/pope.605.0701.

ICBS. (Various years). Statistical Abstract of Israel. Jerusalem: Israel Central Bureau of Statistics.

Inglehart, R. and Baker, W.E. (2000). Modernization, cultural change, and the persistence of traditional values. American Sociological Review 65(1): 19-51. doi:10.2307/2657288.

Inglehart, R. and Welzel, C. (2005). Modernization, Cultural Change, and Democracy: The Human Development Sequence. New-York: Cambridge University Press.

Inglehart, R. and Welzel, C. (2010). Changing mass priorities: The link between modernization and democracy. Perspectives on Politics 8(2): 551-566. doi:10.10 17/S1537592710001258.

Israel, Ministry of Interior (2011). Madrich Le-mitchatnim (Guide for marrying couples). Jerusalem: Ministry of Interior. www.gov.il/FirstGov/TopNav/ Situations/SSituationsInLife/SMarriage/SMAlternativeMarriage/SMACivil/ (Retrieved 6.2.2011, Hebrew). 
Israel Association for the Advancement of Women's Health (2003). Seker Hevrat Geokartografia Be-nose Shimush Be-emtsaei Menia (Survey of Geocartography on the usage of contraception). http://www.la-briut.org.il/article/?id=f1427063b 8b1f73f18fe246b149404e3.(Retrieved 16.09.2010, Hebrew).

Israel Central Bureau of Statistics (2010a). Social Survey 2009: Jewish Tradition Observance and Changes in Religiosity of the Jewish population in Israel. Press release12.9.2010.www.cbs.gov.il (Retrieved 20.09.10, Hebrew).

Israel Central Bureau of Statistics (2010b). Ochlusia Be-Israel 1990-2009 (The Population in Israel 1990-2009).In: Statistilite 108: Jerusalem: Israel Central Bureau of Statistics. (Hebrew).

Katz, R. (2001). Effects of migration, ethnicity, and religiosity on cohabitation.Journal of Comparative Family Studies 32(4): 587-599.

Katz-Gerro, T., Raz, S., and Yaish, M. (2009). How do class, status, ethnicity and religiosity shape cultural omnivorousness in Israel? Journal of Cultural Economics 33(1): 1-17. doi:10.1007/s10824-008-9088-5.

Kohler, H.-P., Billari, F.C., and Ortega, J.A. (2002). The emergence of lowest-low fertility in Europe during the 1990s.Population and Development Review 28(4): 641-680. doi:10.1111/j.1728-4457.2002.00641.x.

Landau, R. (2003). Religiosity, nationalism and human reproduction: The case of Israel. International Journal of Sociology and Social Policy 23(12): 64-80. doi:10.11 08/01443330310790408.

Lavee, Y. and Katz, R. (2003). The family in Israel: Between tradition and modernity. Marriage and Family Review 35(1-2): 193-217. doi:10.1300/J002v35n01_11.

Lazerwitz, B. and Tabory, E. (2002). National religious context and familial religiosity within a Jewish framework. Review of Religious Research 44(1): 22-37. doi:10.2 $307 / 3512155$.

Lesthaeghe, R. (1998). On theory development: Application to the study of family formation. Population and Development Review 24(1): 1-14. doi:10.2307/ 2808120.

Lesthaeghe, R. (2010). The unfolding story of the second demographic transition. Population and Development Review 36(2): 211-251. doi:10.1111/j.1728-4457. 2010.00328.x. 
Lesthaeghe, R. and Neidert, L. (2006). The second demographic transition in the United States: Exception or textbook example? Population and Development Review 32(4): 669-698. doi:10.1111/j.1728-4457.2006.00146.x.

Lesthaeghe, R. and Surkyn, J. (2006). When history moves on - Foundations and diffusion of a second demographic transition. In: Jayakodi, R., Thornton, A.., and Axinn, W. (eds.). International family change: Ideational perspectives. New York: Lawrence Erlbaum and Associates, Taylor \& Francis Group: 81-118.

Lesthaeghe, R. and van de Kaa, D.J. (1986). Twee Demografische Transities? ('Two demographic transitions?'). In: Lesthaeghe, R. and van de Kaa, D.J. (eds.). Bevolking: Groei en Krimp, Mens en Maatschappij. Deventer: Van LoghumSlaterus: 9-24.

Liebman, C.S. (1993). Religion and Modernity: The Special case of Israel. In: Liebman, C.S. and Katz, E. (eds.). The Jewishness of Israelis: Responses to the Guttman Report. New York: SUNY press: 85-103.

Liebman, C.S. (1997). Reconceptualizing the culture conflict among Israeli Jews. Israel Studies 2(2): 172-189. doi:10.2979/ISR.1997.2.2.172.

Liebman, C.S. and Don-Yehiya, E.(1984). Religion and Politics in Israel. Bloomington: Indiana University Press.

Malnar, B. (1999). Images of Modern Family. In: Tos, N., Mohler, P.Ph., and Malnar, B. (eds.). Modern Society and Values: A Comparative Analysis Based on ISSP Project. Ljubljana, Mannheim: University of Ljubljana, ZUMA, Center for Survey Research and Methodology: 217-239.

Manski, C.F. and Mayshar, J. (2003). Private incentives and social interactions: Fertility puzzles in Israel. Journal of European Economic Association 1(1): 181-211. doi:10.1162/154247603322256800.

McQuillan, K. (2004). When does religion influence fertility? Population and Development Review 30(1): 25-56.doi:10.1111/j.1728-4457.2004.00002.x.

Montgomery, M.R. and Casterline, J.B. (1996). Social learning, social influence, and new models of fertility. Population and Development Review 22: 151-175. doi:10.2307/2808010.

Morgan, S.P. and Berkowitz King, R. (2001). Why have children in the 21st century? Biological predisposition, social coercion, rational choice. European Journal of Population 17(1): 3-20. doi:10.1023/A:1010784028474. 
Nahmias, P. (2004). Fertility behaviour of recent immigrants to Israel: A comparative analysis of immigrants from Ethiopia and the former Soviet Union. Demographic Research 10(4): 83-120. doi:10.4054/DemRes.2004.10.4.

Nauck, B. and Klaus, D. (2007). The varying value of children: Empirical results from eleven societies in Asia, Africa and Europe. Current Sociology 55(4): 487-503. doi:10.1177/0011392107077634.

Netherlands, Inspection for Healthcare (2010). Jaarrapportage 2009 van de Wet afbrekingzwangerschap (Annual Report of the Termination of Pregnancy Act).www.igz.nl/Images/2010-12\%20Jaarrapportage\%20WAZ\%202009_tcm 294-292695.pdf (Retrieved 16.02.11, Dutch).

Okun, B.S. (1996). Sex preferences, family planning and fertility: An Israeli subpopulation in transition. Journal of Marriage and Family 58(2): 469-475. doi: $10.2307 / 353510$.

Okun, B.S. (1997). Family planning in the Jewish population of Israel: Correlates of withdrawal use. Studies in Family Planning 28(3): 215-227. doi:10.2307/21 37889 .

Okun, B.S. (2000). Religiosity and Contraceptive Method Choice: The Jewish population in Israel. European Journal of Population 16(2): 109-132. doi:10. 1023/A:1006322125744.

Paltiel, A., Sepulchre, M., Kornilenko, I., and Maldonado, M. (2012). Long-Range Population Projections for Israel: 2009-2059. Technical paper 27. Jerusalem: Central Bureau of Statistics. (Hebrew).

Perelli-Harris, B., Sigle-Rushton, W., Lappegard, T., Jasilioniene, J., Di Giulio, P., Keizer, R., Koeppen, K., Berghammer, C., and Kreyenfeld, M. (2009). Examining nonmarital childbearing in Europe: How does union context differ across countries? Rostock: Max Planck Institute for Demographic Research (MPIDR working paper, WP-2009-021).

Philippov, M. and Bystrov, E. (2011). All by myself? The paradox of citizenship among the FSU immigrants in Israel. In: Ben-Porat, G. and Turner, B.S. (eds.) The Contradictions of Israeli Citizenship: Land, Religion and State. Milton Park, Abingdon, Oxon: Routledge.

Safir, M.P., Rosenmann, A., and Kloner, O. (2003). Tomboyism, sexual orientation, and adult gender roles among Israeli women. Sex Roles 48(9-10): 401-410. doi.:10.1023/A:1023522410882. 
Sapir, G. and Statman, D. (2009). Religious marriage in a liberal state. Cardozo Law Review de novo 30(6): 2855-2880.

Schellekens, J. (2009). Family allowances and fertility: Socioeconomic differences. Demography 46(3): 451-468. doi:10.1353/dem.0.0067.

Semyonov, M. and Lewin-Epstein, N. (1991). Suburban labormarkets, urban labormarkets, and gender inequality in earnings. The Sociological Quarterly 32(4): 611-620. doi:10.1111/j.1533-8525.1991.tb00157.x.

Shamir, M. and Arian, A. (1999). Collective identity and electoral competition in Israel. American Political Science Review 93(2): 265-277. doi:10.2307/2585395.

Smooha, S. (2004). Jewish Ethnicity in Israel: Symbolic or real? In: Rebhun, U. and Waxman, C.I. (eds.). Jews in Israel: Contemporary Social and Cultural patterns. Hanover, NH: Brandeis University Press.

Smooha, S. (2005). Is Israel Western? In: Ben-Rafael, E. and Sternberg, Y. (eds.). Comparing Modernities: Pluralism versus Homogeneity: Essays in Homage to Shmuel N. Eisenstadt. Leiden and Boston: Brill Academic Publishers: 413-442.

Smooha, S. (2010). Hartsaat Nasi Ha-aguda Ha-sotsiologit Ha-Israelit Be-shnat (2009): Ha-hevra Ha-Israelit: Kechol Ha-havarot o Mikre Yotse Dofen? (Israeli Sociological Society Presidential Address in 2009: Israeli Society: Like Other Societies or an Exceptional Case?). Sociologia Yisraelit 11(2): 297-302. (Hebrew).

Sobotka, T. (2008). Overview Chapter 6: The diverse faces of the second demographic transition in Europe. Demographic Research 19(8): 171-224. doi:10.4054/Dem Res.2008.19.8.

Sobotka, T. and Toulemon, L. (2008). Overview Chapter 4: Changing family and partnership behaviour: Common trends and persistent diversity across Europe. Demographic Research 19(6): 85-138. doi:10.4054/DemRes.2008.19.6.

Sobotka, T., Zeman, K., and Kantorová, V. (2003). Demographic shifts in the Czech Republic after 1989: A second demographic transition view. European Journal of Population 19(3): 249-277. doi:10.1023/A:1024913321935.

Stier, H. and Lewin-Epstein, N. (2000). Women's part-time employment and gender inequality in the family. Journal of Family Issues 21(3): 390-410. doi:10.1177/019251300021003006. 
Stier, H. and Yaish, M. (2008). The determinants of women's employment dynamics: The case of Israeli women. European Sociological Review 24(3): 363-377. doi:10.1093/esr/jen010.

Strum, P. (1989). Women and the politics of religion in Israel. Human Rights Quarterly 11(4): 483-503. doi:10.2307/762088.

Suckow, J. (2008). Dependence of the Values of Children on Socio-Structural Characteristics: The Case of Israel and Palestine. In: Zheng, G., Leung, K., and Adair, J.G. (eds.). Perspectives and Progress in Contemporary Cross-Cultural Psychology. Xi'an: International Association for Cross-Cultural Psychology: 119-128.

Surkyn, J. and Lesthaeghe, R. (2004). Value Orientations and the Second Demographic Transition (SDT) in Northern, Western and Southern Europe: An Update. Demographic Research 3(3): 45-86. doi:10.4054/DemRes.2004.S3.3.

Toren, N. (2003).Tradition and transition: Family change in Israel. Gender Issues 21(2): 60-76. doi:10.1007/s12147-003-0017-9.

van de Kaa, D.J. (1987). Europe's Second Demographic Transition. Population Bulletin 42(1): 1-59.

van de Kaa, D.J. (1996). Anchored narratives: The story and findings of half a century of research into the determinants of fertility. Population Studies 50(3): 389-432. doi:10.1080/0032472031000149546.

van de Kaa, D.J. (1997). Options and Sequences: Europe's Demographic Patterns. Journal of the Australian Population Association 14(1): 1-29.

van de Kaa, D.J. (2001). Postmodern Fertility Preferences: From Changing Value Orientation to New Behavior. Population and Development Review 27: 290-331.

VID (2010). European Demographic Data Sheet 2010. Vienna: Vienna Institute of Demography. Washington DC: Population Reference Bureau.

Welzel, C. (2012). Breaking Free: People Power and the Human Quest for Emancipation. NY: Cambridge University Press. (forthcoming).

Welzel, C. and Inglehart, R. (2010). Agency, values and well-being: A human development model. Social Indicators Research 97(1): 43-63. doi:10.1007/ s11205-009-9557-z. 
Welzel, C., Inglehart, R., and Klingemann, H.-D. (2003). The theory of human development: A cross-cultural analysis. European Journal of Political Research 42: $341-379$.

Yaish, M. and Kraus, V. (2003). The consequences of economic restructuring for the gender earnings gap in Israel, 1972-1995. Work, Employment \& Society 17(1): 5-28. doi:10.1177/0950017003017001250.

Yuchtman-Ya'ar, E. (2002). Value priorities in Israeli Society: An Examination of Inglehart's Theory of Modernization and Cultural Variation. Comparative Sociology 1(3-4): 347-367. 